\title{
How much LH do the Leydig cells see?
}

\author{
B P Setchell, P Pakarinen ${ }^{1}$ and I Huhtaniemi ${ }^{1}$
}

Pediatric Endocrinology Unit, Karolinska Hospital, Stockholm, Sweden and Department of Anatomical Sciences, University of Adelaide, Adelaide, Australia

${ }^{1}$ Department of Physiology, University of Turku, Finland

(Requests for offprints should be addressed to B P Setchell, Department of Anatomical Sciences, University of Adelaide, Adelaide 5005, Australia; Email: brian.setchell@adelaide.edu.au)

\begin{abstract}
The purpose of this study was to assess the concentrations of LH that Leydig cells are exposed to upon in vivo stimulation of steroidogenesis. The concentrations of $\mathrm{LH}$ were measured in rats in testicular interstitial extracellular fluid, seminiferous tubular fluid and blood plasma from testicular veins from one testis before and from the other testis of the same rats after an intravenous injection of gonadotrophin-releasing hormone $(\mathrm{GnRH})$ or saline, and compared with the concentrations in blood plasma from a peripheral vein. The concentrations of $\mathrm{LH}$ in interstitial fluid surrounding the Leydig cells before the injections were about $10 \%$ of the levels in blood plasma, and showed no significant rise at $15 \mathrm{~min}$ and a much smaller rise at later times in rats injected with $\mathrm{GnRH}$ than those seen in blood plasma from either of the two sources, which were similar. The concentrations of $\mathrm{LH}$ in tubular fluid were
\end{abstract}

even lower and showed no change after GnRH. Testosterone concentrations in testicular cells, interstitial fluid and testicular venous blood plasma were significantly increased by $15 \mathrm{~min}$ after $\mathrm{GnRH}$, when compared with saline-injected controls, with no change in the levels in tubular fluid. The rise in testosterone concentrations in testicular venous plasma after GnRH was smaller than those in the cells and interstitial fluid. In conclusion, the concentrations of $\mathrm{LH}$ reaching the testicular interstitial fluid were only about one-tenth of that measured in the circulation, presumably because the endothelial cells restrict access of the hormone to the interstitial fluid. This indicated that either the Leydig cells are extremely sensitive to LH stimulation or that testicular endothelial cells modulate the action of $\mathrm{LH}$ on the Leydig cells.

Journal of Endocrinology (2002) 175, 375-382

\section{Introduction}

It is an article of endocrinological dogma that the Leydig cells in the testis are stimulated to secrete testosterone by luteinizing hormone $(\mathrm{LH})$ released by the pituitary into the blood stream. Furthermore, the LH is not released continuously into the blood, but in pulses with a rapid increase in plasma LH concentrations in rats within 5 to $10 \mathrm{~min}$ after each pulsatile release followed by a gradual decline lasting 50 to $70 \mathrm{~min}$ afterwards (Ellis \& Desjardins 1982, Pierroz et al. 1999). Little consideration has been given to the question of how that $\mathrm{LH}$ reaches the Leydig cells, which certainly have receptors for LH (Dufau 1995) and are bathed in interstitial extracellular fluid (IEF) (Maddocks \& Setchell 1988). However, Setchell (1994) showed that the concentrations of endogenous $\mathrm{LH}$ in ram testicular lymph, arising largely from the interstitial tissue of the testis where the Leydig cells are located, rose only very slightly during the $3 \mathrm{~h}$ after an intravenous injection of LH-releasing hormone, more properly referred to as gonadotrophin-releasing hormone $(\mathrm{GnRH})$, while the concentration of LH in the blood plasma rose approximately ten times within 15 to $30 \mathrm{~min}$ after the injection.
Then Turner \& Rhoades (1995) showed that when radioactively labelled iodinated human LH was infused into the testicular artery in rats, the isotope concentration in testicular interstitial fluid was only $3 \cdot 6 \%$ of that in the plasma after $10 \mathrm{~min}$ of infusion. However, there are shortcomings to both these studies. Testicular lymph collected from a catheter in the spermatic cord is quite a long way downstream from the interstitial fluid inside the testis, and iodinated human LH infused into the testicular artery of a rat may not behave in that species like the native hormone. Previously, it had been shown that the concentration in interstitial fluid from the rat testis of iodinated human chorionic gonadotophin (hCG; a hormone like, but not identical to, rat $\mathrm{LH}$ in structure and function) was only about $20 \%$ of plasma levels $2 \mathrm{~h}$ after subcutaneous injection of radioactively labelled hormone. Shorter times after injection were not studied, and the concentration of iodinated hCG in the IEF continued to increase up to $8 \mathrm{~h}$ after injection (Sharpe 1981). However, hCG contains about 237 amino acids, compared with about 213 for rat LH; probably more importantly, hCG has at least six glycosylation sites on its $\beta$-chain, compared with one for rat $\mathrm{LH}$, which would probably affect its rate of passage 
from the blood into the testis. Certainly, hCG has a much longer half-life in vivo after injection than native $\mathrm{LH}$ (Bousfield et al. 1994). We therefore believe that the studies with hCG may have given misleading results and that studies should be done with native LH from the same species.

Because of the controversy concerning the earlier studies, new data using a different approach were needed. The present study was undertaken when, with the development of a novel ultrasensitive assay for rat LH (Haavisto et al. 1993), it became possible to analyse small samples of blood and other fluids for this hormone, in a way that had not been possible previously. It was hoped to monitor the changes in concentration of the endogenous hormone directly in the interstitial fluid around the Leydig cells and fluid from the lumina of the seminiferous tubules, and to relate these changes to changes in the concentrations in peripheral venous (PV) and testicular venous (TV) blood, as well as the resultant alterations in testosterone secretion by the Leydig cells.

\section{Materials and Methods}

\section{Animals and treatments}

A total of 44 adult male Sprague-Dawley rats was used. Of these, 36 weighing between 360 and $429 \mathrm{~g}$ in experiment 1 were supplied by B and K Universal, Sollentuna, Sweden, and eight weighing between 340 and $360 \mathrm{~g}$ in experiment 2 by the Central Animal House of the University of Adelaide.

In experiment 1 , the rats were anaesthetized with intraperitoneal pentobarbitone sodium $(50 \mathrm{mg} / \mathrm{kg}$ body weight) and the left jugular vein was cannulated. In this experiment, two sets of samples were collected from each rat. In the first set, referred to as the time 0 samples, a heparinized PV blood sample $(1 \mathrm{ml})$ was removed through the jugular catheter and then a TV blood sample was collected from the veins on the surface of one testis under the head of the epididymis near the efferent ducts, alternatively left or right, using heparinized haematocrit tubes as described by Galil \& Setchell (1988); that testis was then removed and IEF collected by opening the capsule and irrigating the parenchyma with $2 \mathrm{ml}$ ice-cold isotonic mannitol, containing $5 \mathrm{mM}$ lithium chloride, with a syringe and blunted needle introduced into three or four sites within the tissue. This enabled collection of most of the IEF, the total volume of which is normally about $100 \mu \mathrm{l}$, diluted with the mannitol solution. The testis was then decapsulated and the parenchyma forced through a 21 gauge needle. The resultant cell dispersion was centrifuged to yield a cell sediment, including both interstitial and tubular cells and a fluid supernatant, previously (Setchell et al. 1976, 2000) shown to represent largely seminiferous tubular fluid (UF). Then either $0.7 \mathrm{ml}$ saline (12 rats) or GnRH (LH-releasing hormone;
Sigma-Aldrich, Stockholm, Sweden; $1.5 \mu \mathrm{g}$ or $0.5 \mu \mathrm{g}$ in each of ten rats or $0.15 \mu \mathrm{g}$ in four rats) in $0.7 \mathrm{ml}$ saline was injected through the jugular catheter. A second batch of samples, referred to as the time $t$ samples, was collected from each rat $15,30,60$ or 120 min later, using the same sampling procedure with the contralateral testis. Finally, a second heparinized PV blood sample was removed from the posterior vena cava using a syringe and needle, and the animal killed with an overdose of anaesthetic. Each sampling procedure including PV blood collection took approximately $3 \mathrm{~min}$.

The blood samples were centrifuged to separate blood plasma, and all samples were frozen until analysis. The extent of dilution of the IEF by the irrigating mannitol solution was estimated by analysing the fluid for sodium concentration by flame photometry, assuming that the sodium content of the fluid in situ was the same as plasma (Setchell et al. 2000). The extent of dilution of the supernatant fluid with the mannitol solution was estimated by analysing for lithium by flame photometry.

In the second experiment, eight adult rats were anaesthetized and four were injected with $0.7 \mathrm{ml}$ saline through one jugular vein, and the other four each with $1.5 \mu \mathrm{g}$ GnRH (Fertagyl; Intervet Australia, Castle Hill, Australia). IEF was collected $15 \mathrm{~min}$ later from one testis by the mannitol irrigation technique described above, and from the other testis after ligating the spermatic cord and removal from the rat, by making a nick in the capsule and suspending the testis in a tube overnight in the refrigerator (Sharpe \& Cooper 1983). With this technique, $109 \pm 6 \mu \mathrm{l}$ fluid was collected from the four control animals and $123 \pm 9 \mu \mathrm{l}$ from the four rats injected with GnRH. A peripheral blood sample was then removed from the posterior vena cava and the animal killed with an overdose of anaesthetic. The samples of IEF and blood plasma were analysed for $\mathrm{LH}$.

\section{Hormone measurements}

Blood plasma samples, diluted IEF and the seminiferous UF were analysed for LH by a time-resolved immunofluorometric assay (Delfia; Wallac OY, Turku, Finland, as described by Haavisto et al. 1993) and for testosterone by a solid-phase RIA (Coat-a-Count; Diagnostic Product Corporation, Los Angeles, CA, USA). The sensitivity of the LH assay was $0.5 \mathrm{pg}$ (NIH RP-2)/well, and when the sample dilutions (1:1 for plasma, approximately 1:20 for IEF) and volumes ( $25 \mu \mathrm{l}$ for plasma, $75 \mu \mathrm{l}$ for IEF) were taken into account, the sensitivities corrresponded to concentrations of $0.01 \mathrm{ng} / \mathrm{ml}$ for plasma and approximately $0.06 \mathrm{ng} / \mathrm{ml}$ for IEF, the exact value for the latter depending on the dilution for that particular sample. If the assay gave values for IEF less than the sensitivity, as happened in only five out of 40 samples, all second samples from saline-injected rats, a value corresponding to the limit of sensitivity, was used in 
Table 1 The concentrations of LH (ng/ml RP-2) in fluids (PV: blood plasma from the jugular vein or posterior vena cava; TV: blood plasma from testicular veins on the testis; IEF: interstitial extracellular fluid from the testis) in sets of two samples from the same rats, before (time 0 ) and after (time t) injection with either saline or GnRH (1.5 or $0.5 \mu \mathrm{g})$ at time 0 . The two doses gave similar responses, and the data from these rats have been pooled. Values are means \pm S.E.M.; six saline- and eight GnRH-injected animals at 15 min, and two saline- and four $\mathrm{GnRH}$-injected animals at other times

\begin{tabular}{|c|c|c|c|c|c|c|}
\hline & Treatment & $\begin{array}{l}\text { Sample } \\
\text { time }\end{array}$ & $t=15 \mathrm{~min}$ & $t=30 \mathrm{~min}$ & $t=60 \mathrm{~min}$ & $t=120 \mathrm{~min}$ \\
\hline \multicolumn{7}{|c|}{ Source } \\
\hline \multirow{3}{*}{ PV } & & $\mathrm{t}$ & $0 \cdot 240 \pm 0.071^{t \dagger}$ & $0.55 \pm 0.44$ & $0 \cdot 31 \pm 0 \cdot 02$ & $0 \cdot 19 \pm 0 \cdot 00^{\neq \neq}$ \\
\hline & $\mathrm{GnRH}$ & 0 & $0 \cdot 590 \pm 0 \cdot 090$ & $0 \cdot 66 \pm 0 \cdot 11$ & $0 \cdot 46 \pm 0 \cdot 09$ & $0 \cdot 50 \pm 0 \cdot 16$ \\
\hline & & $\mathrm{t}$ & $3 \cdot 510 \pm 0 \cdot 310^{* * *}$ & $6 \cdot 14 \pm 1 \cdot 3^{* * *}$ & $5 \cdot 27 \pm 1 \cdot 5^{\text {*** }}$ & $2 \cdot 02 \pm 0 \cdot 49^{\star}$ \\
\hline \multirow{2}{*}{ TV } & $\mathrm{GnRH}$ & 0 & $0.640 \pm 0.084$ & $0 \cdot 85 \pm 0 \cdot 17$ & $0 \cdot 74 \pm 0.34$ & $0 \cdot 70 \pm 0 \cdot 20$ \\
\hline & & t & $3 \cdot 370 \pm 0 \cdot 310^{* * *}$ & $6 \cdot 48 \pm 1 \cdot 3^{* * *}$ & $6 \cdot 22 \pm 1 \cdot 4^{* * *}$ & $2 \cdot 51 \pm 0 \cdot 56^{*}$ \\
\hline \multirow[t]{4}{*}{ IEF } & Saline & 0 & $0.079 \pm 0.015$ & $0.056 \pm 0.007$ & $0 \cdot 075 \pm 0 \cdot 020$ & $0 \cdot 059 \pm 0 \cdot 020$ \\
\hline & & $\mathrm{t}$ & $0 \cdot 102 \pm 0 \cdot 021$ & $0 \cdot 061 \pm 0 \cdot 001$ & $0 \cdot 131 \pm 0 \cdot 074$ & $0 \cdot 047 \pm 0 \cdot 005$ \\
\hline & $\mathrm{GnRH}$ & 0 & $0 \cdot 088 \pm 0.032$ & $0 \cdot 078 \pm 0.028$ & $0 \cdot 063 \pm 0 \cdot 011$ & $0 \cdot 067 \pm 0.015$ \\
\hline & & t & $0 \cdot 100 \pm 0 \cdot 008$ & $0.23 \pm 0.063^{*}$ & $0 \cdot 28 \pm 0 \cdot 12^{* *}$ & $0 \cdot 23 \pm 0 \cdot 076^{*}$ \\
\hline
\end{tabular}

${ }^{*} P<0 \cdot 05,{ }^{* *} P<0 \cdot 01,{ }^{* * *} P<0 \cdot 01$ greater than corresponding time 0 value (three-way ANOVA and least square mean test). ${ }^{+} P<0.01$ less than corresponding time 0 value (paired $t$-test).

${ }^{\ddagger \ddagger} P<0 \cdot 01$ pooled $30-, 60$ - and 120 -min values less than corresponding pooled time 0 values (paired $t$-test).

the calculations. When known amounts of the LH standard were added to a pool of IEF, to assess the sensitivity, precision and accuracy of the assay, an increment of $0 \cdot 5 \mathrm{pg}$ could be detected, and the dose/signal ratios increased in a linear fashion.

For the testosterone assay, $50 \mu \mathrm{l}$ samples of PV plasma, $25 \mu \mathrm{l}$ samples of IEF diluted in mannitol and $5 \mu \mathrm{l}$ samples of TV plasma and UF were taken, and the volumes made up to $50 \mu \mathrm{l}$ with the blank solution supplied with the kit. The cell sediment was assayed for testosterone by homogenizing the weighed cells in $5 \mathrm{ml} 0 \cdot 1 \mathrm{M}$ sodium phosphate buffer, $\mathrm{pH} 7 \cdot 4$, and diluting tenfold the supernatant following centrifugation at $2000 \boldsymbol{g}$ for $20 \mathrm{~min}$ (Nnane et al. 1999). Fifty microlitres of the diluted supernatant were assayed, and the concentration in the original cell fraction calculated as $\mathrm{pmol} / \mathrm{g}$ tissue. This technique has been shown to give similar values to assays of ether extracts of rat testes (K Svechnikov, personal communication).

\section{Statistical analyses}

Data were analysed by three-way ANOVA (treatment: $\mathrm{GnRH}$ or saline; sample: time 0 or time t; time after injection: 15, 30, 60 or $120 \mathrm{~min}$ ) and least square mean (Super-ANOVA, Abacus Concepts, Berkeley, CA, USA) and by paired $t$-test when comparing pairs of samples from the same rat before and after injection. The ratios of values after various times after injection (time $t$ sample) to the initial values (time 0 sample) from the same rat were subjected to Mann-Whitney $U$ test, as these t/ 0 ratio values were not normally distributed.

\section{Results}

The LH concentrations in PV and TV blood plasma were very similar, and both had increased about five times by 15 min after injection of GnRH at the two higher doses, which gave a similar response. The concentrations reached maximal values of about ten times control after $30 \mathrm{~min}$, remained at about the same level after $60 \mathrm{~min}$, then fell slightly after $120 \mathrm{~min}$ (Table 1). As the responses to the two higher doses of GnRH were similar, the data from these two doses have been pooled. The lowest dose of GnRH produced a smaller response, and the data from these four animals have not been included in the Tables. In the saline-injected animals, the LH concentrations in the PV and TV plasma were less than at time 0 in the samples collected after $15 \mathrm{~min}$, and this difference was also significant in the samples collected after 30,60 and $120 \mathrm{~min}$, when the data from these three time-points were pooled (Table 1).

The concentration of LH in the IEF was about onetenth of that in the blood plasma in the time 0 samples, and was not significantly increased $15 \mathrm{~min}$ after $\mathrm{GnRH}$, either in absolute values (Table 1) or in the ratio of the value in the sample collected at $15 \mathrm{~min}$ after injection to that in the sample collected from the same rat before the injection of GnRH or saline (15 min t/0 ratio) when compared with 


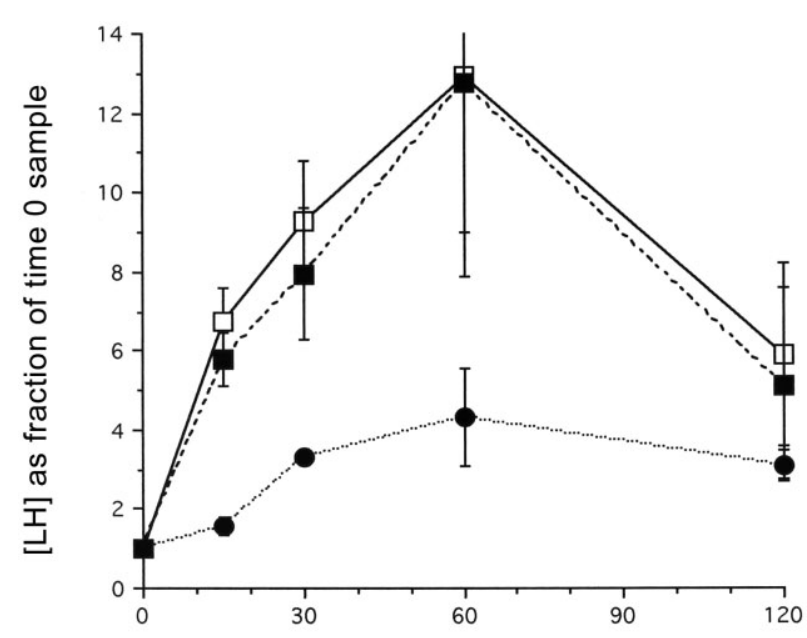

Time (min) after injection of LHRH

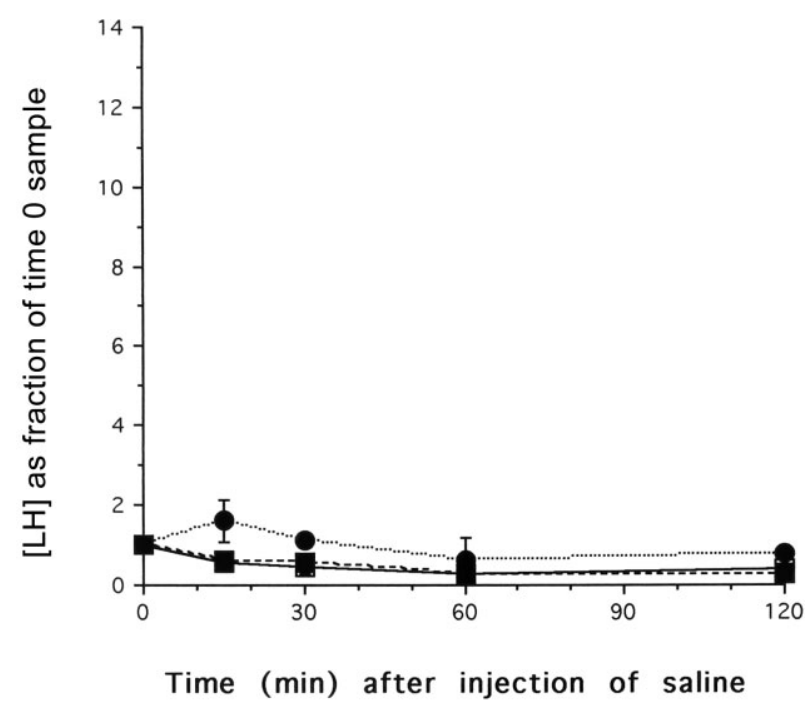

Figure 1 The means of the t/0 ratios for individual animals of the concentrations of $\mathrm{LH}([\mathrm{LH}])$ at various times after injection to those before injection (time 0) in the same rats in PV plasma ( $\square$ ), TV plasma ( $\mathbf{\square})$ and IEF $(\mathbf{O})$ in rats injected with either (upper) 1.5 or $0.5 \mu \mathrm{g} \mathrm{GnRH}$ or (lower) saline $(0.7 \mathrm{ml})$ at time 0 . Bars represent S.E.M.

rats given saline $(1.59 \pm 0.22$ vs $1.59 \pm 0.53$ respectively, $\mathrm{U}=17$, not significant; Fig. 1). There were significant rises in LH in IEF after 30, 60 and 120 min (Table 1), but the increases were proportionately much less than in the blood (Fig. 1) and the concentrations reached at these times were still less than $5 \%$ of those in the plasma at the same times. The concentrations of LH in the IEF did not change significantly with time in the control animals (Table 1).

The concentrations of $\mathrm{LH}$ in the UF were even lower than in IEF $(0 \cdot 044 \pm 0 \cdot 008 \mathrm{ng} / \mathrm{ml}, n=16)$ at time 0 , and were not affected by injection of $\mathrm{GnRH}$ in the eight animals, two each at 15, 30, 60 and $120 \mathrm{~min}$, in which this fluid was analysed $(0 \cdot 040 \pm 0 \cdot 011 \mathrm{ng} / \mathrm{ml})$.

The concentrations of testosterone $[\mathrm{T}]$ in the cellular fraction after centrifugation of the dispersed testicular parenchyma were higher than in the IEF, which was, in turn, higher than either TV plasma or UF. As expected, all were much higher than the levels in PV plasma (Table 2). The $[T]$ in the cells, IEF, UF and TV blood were significantly increased only after 60 and $120 \mathrm{~min}$, and in PV blood only after $120 \mathrm{~min}$; in fact, at $15 \mathrm{~min}$ after GnRH, the [T] in PV was actually significantly lower than at time 0 , as it was in the saline-injected controls (Table 1 ). However, if the $15 \mathrm{~min} \mathrm{t} / 0$ ratio was calculated (Fig. 2), these ratios were significantly higher, by Mann-Whitney $\mathrm{U}$ test, in the GnRH-injected rats than in those receiving saline $(1.47 \pm 0.096$ vs $0.97 \pm 0.085$ respectively, $U=8$, $P=0.021$ for cells, $0.94 \pm 0.088$ vs $0.80 \pm 0.06$ for TV and $1.09 \pm 0.084$ vs $0.83 \pm 0.053$ for IEF, $U=7, P=0.015$ for both). These calculations were not made for the later time-points, as even a value of $U=0$ did not reach significance with only four and two values in the two groups. The $\mathrm{t} / 0$ ratios for $[\mathrm{T}]$ in $\mathrm{UF}$ at $15 \mathrm{~min}$ were not affected significantly by injection of GnRH (1.04 $\pm 0 \cdot 07$ vs $1 \cdot 01 \pm 0 \cdot 11, U=20$, not significant). The calculation of this ratio was done to overcome the effect of the large variability in the testosterone levels in different rats and was justified by the high correlations between the time 0 and time $\mathrm{t}$ samples from the 12 rats injected with saline $(r=0.658$ for testosterone in cells, 0.748 for UF, 0.710 for IEF, 0.865 for TV and 0.936 for PV, all $P<0.001$ ).

There were significant linear correlations between the [T] at time 0 in the cell fraction (cell $[\mathrm{T}]$ ) and IEF $(r=0.503, P<0 \cdot 01, n=36)$, UF $(r=0 \cdot 442, P<0 \cdot 01)$, TV $(r=0.457, \quad P<0.01)$ and PV $(r=0.478, \quad P<0.01) \quad[\mathrm{T}]$, although the slopes of all the lines were less than unity, so that a doubling in cell $[\mathrm{T}]$ was associated with a $54 \%$ increase in IEF, a $73 \%$ increase in UF but only a $45 \%$ increase in TV [T]. Using all 24 samples collected after all three doses of $\mathrm{GnRH}$, significant linear regressions were also found $(r=0.573,0.542, P<0.001,0.476$ and 0.501 , $P<0 \cdot 01$ for IEF, UF, TV and PV [T] respectively with cell $[\mathrm{T}])$. However, the slope of the line for TV against cell [T] after GnRH was significantly less than the time 0 regression or the time $t$ regression for the saline-injected rats, so that a doubling in cell $[\mathrm{T}]$ after GnRH was associated with only a 31\% increase in TV [T]. There was no difference between the slopes of the regression lines for UF against cell $[\mathrm{T}]$ between the time 0 and the post-GnRH samples.

A similar situation applied for the relationship between IEF and TV or UF [T]. The correlations were much higher $(r=0.884$ and $0.632, P<0.001$ for TV and UF with IEF $[T]$ respectively at time 0 , and 0.903 and 0.948 for the time $t$ samples after $\mathrm{GnRH}$ ) than for those against the cell [T]. Again, the slope of the line of TV against IEF [T] was significantly lower for the time $\mathrm{t}$ samples than the time 0 samples $(P<0 \cdot 001)$, but there was no difference between 
Table $2[\mathrm{~T}](\mathrm{nmol} / \mathrm{l})$ in PV, TV, IEF and UF, and in the cellular residue (nmol/kg) after centrifugation in the samples from the same animals as in Table 1

\begin{tabular}{|c|c|c|c|c|c|c|}
\hline & Treatment & $\begin{array}{l}\text { Sample } \\
\text { time }\end{array}$ & $t=15 \mathrm{~min}$ & $t=30 \mathrm{~min}$ & $t=60 \mathrm{~min}$ & $t=120 \mathrm{~min}$ \\
\hline $\begin{array}{l}\text { Source } \\
\text { PV }\end{array}$ & $\begin{array}{l}\text { Saline } \\
\text { GnRH }\end{array}$ & $\begin{array}{l}0 \\
t \\
0 \\
t\end{array}$ & $\begin{aligned} 7 \cdot 6 & \pm 1 \cdot 4 \\
4 \cdot 4 & \pm 1 \cdot 3^{\dagger \dagger} \\
10 \cdot 6 & \pm 2 \cdot 0 \\
4 \cdot 8 & \pm 0 \cdot 7^{\text {** }}\end{aligned}$ & $\begin{aligned} 2 \cdot 4 & \pm 0 \cdot 8 \\
0 \cdot 55 & \pm 0 \cdot 05 \\
11 \cdot 1 & \pm 2 \cdot 5 \\
6 \cdot 3 & \pm 1 \cdot 6\end{aligned}$ & $\begin{array}{r}15 \cdot 0 \pm 9 \cdot 6 \\
2 \cdot 5 \pm 0 \cdot 1 \\
8 \cdot 3 \pm 1 \cdot 9 \\
8 \cdot 8 \pm 2 \cdot 5\end{array}$ & $\begin{aligned} 3 \cdot 2 & \pm 0 \cdot 8 \\
0 \cdot 15 & \pm 0 \cdot 05^{\neq \neq, c} \\
4 \cdot 9 & \pm 1 \cdot 9^{\mathrm{a}, \mathrm{b}} \\
14 \cdot 1 & \pm 1 \cdot 8^{\text {aaa, }}\end{aligned}$ \\
\hline TV & $\begin{array}{l}\text { Saline } \\
\text { GnRH }\end{array}$ & $\begin{array}{l}0 \\
t \\
0 \\
t\end{array}$ & $\begin{array}{l}724 \pm 120 \\
584 \pm 106^{\dagger} \\
588 \pm 63 \\
577 \pm 50\end{array}$ & $\begin{array}{l}301 \pm 6^{a} \\
199 \pm 62^{a} \\
598 \pm 83 \\
692 \pm 113\end{array}$ & $\begin{array}{l}362 \pm 55 \\
237 \pm 100 \\
561 \pm 99 \\
921 \pm 199 * a\end{array}$ & $\begin{array}{l}468 \pm 202 \\
108 \pm 18^{\ddagger \mathrm{a}, \mathrm{cc}} \\
362 \pm 100 \\
888 \pm 183^{* *, \mathrm{a}}\end{array}$ \\
\hline $\mathrm{IEF}$ & $\begin{array}{l}\text { Saline } \\
\text { GnRH }\end{array}$ & $\begin{array}{l}0 \\
t \\
0 \\
t\end{array}$ & $\begin{array}{l}959 \pm 145 \\
805 \pm 141^{\dagger} \\
804 \pm 115 \\
712 \pm 129\end{array}$ & $\begin{aligned} 331 & \pm 7 \\
242 & \pm 25 \\
913 & \pm 111 \\
1238 & \pm 152\end{aligned}$ & $\begin{aligned} 1121 & \pm 446 \\
548 & \pm 4 \\
760 & \pm 141 \\
2230 & \pm 360^{* * *, a a a, b b}\end{aligned}$ & $\begin{aligned} 665 & \pm 300 \\
144 & \pm 38^{\mathrm{c}} \\
565 & \pm 192 \\
2074 & \pm 397^{* * *, a a a, b b}\end{aligned}$ \\
\hline UF & $\begin{array}{l}\text { Saline } \\
\text { GnRH }\end{array}$ & $\begin{array}{l}0 \\
t \\
0 \\
t\end{array}$ & $\begin{array}{l}211 \pm 26 \\
208 \pm 29 \\
316 \pm 31 \\
336 \pm 46\end{array}$ & $\begin{array}{l}197 \pm 86 \\
108 \pm 28 \\
341 \pm 80 \\
426 \pm 91\end{array}$ & $\begin{array}{l}281 \pm 89 \\
166 \pm 8 \\
291 \pm 80 \\
706 \pm 161^{* * *, a a a, b b}\end{array}$ & $\begin{array}{l}270 \pm 156 \\
217 \pm 167^{\ddagger} \\
209 \pm 56 \\
679 \pm 176^{* * *, a a, b}\end{array}$ \\
\hline Cells & $\begin{array}{l}\text { Saline } \\
\text { GnRH }\end{array}$ & $\begin{array}{l}0 \\
t \\
0 \\
t\end{array}$ & $\begin{aligned} 1010 & \pm 176 \\
965 & \pm 165 \\
884 & \pm 90 \\
1394 & \pm 427\end{aligned}$ & $\begin{aligned} 472 & \pm 126 \\
302 & \pm 74 \\
1234 & \pm 135 \\
1677 & \pm 163\end{aligned}$ & $\begin{aligned} 856 & \pm 316 \\
426 & \pm 72 \\
1058 & \pm 150 \\
2490 & \pm 1073^{*, a}\end{aligned}$ & $\begin{aligned} 1033 & \pm 647 \\
329 & \pm 184 \\
820 & \pm 241 \\
3937 & \pm 735^{* * *, a a a, b b b}\end{aligned}$ \\
\hline
\end{tabular}

${ }^{*} P<0 \cdot 05,{ }^{*} P<0 \cdot 01,{ }^{* * *} P<0 \cdot 001$ different from time 0 value (three-way ANOVA and least square mean).

${ }^{\dagger} P<0.05,{ }^{\dagger} P<0.01$ less than corresponding time 0 value (paired $t$-test).

${ }^{\ddagger} P<0 \cdot 05,{ }^{\ddagger \ddagger} P<0 \cdot 01$ pooled values for 30 -, 60 - and 120 -min values less than corresponding pooled time 0 values (paired $t$-test).

${ }^{\text {a } P<0.05}$, aa $P<0 \cdot 01$, aaa $P<0.001$ different from 15-min value (ANOVA and least square mean).

b $P<0 \cdot 05$, b $P<0 \cdot 01$, bbb $P<0 \cdot 001$ different from 30-min value (ANOVA and least square mean).

${ }^{\mathrm{C}} \mathrm{P}<0.05$, ${ }^{\mathrm{cc}} \mathrm{P}<0.001$ pooled $30-, 60$ - and 120 -min values less than 15 -min value (ANOVA and least square mean).

the slopes of the regressions of UF against IEF [T] at time 0 or after GnRH. The correlations between PV [T] and TV [T] for the time 0 samples $(r=0 \cdot 228, n=36)$ or at time $\mathrm{t}$ after GnRH $(r=0 \cdot 257, n=24)$ were not significant.

In experiment 2 , the concentrations of $\mathrm{LH}$ in the samples of IEF collected by the mannitol irrigation technique were comparable to those reported in experiment 1 , and significantly higher than in fluid collected by the drip technique at time $0(0 \cdot 151 \pm 0 \cdot 015$ vs $0 \cdot 074 \pm 0 \cdot 017$, $n=4)$, and not significantly different at $15 \mathrm{~min}$ $(0.175 \pm 0.041$ vs $0.308 \pm 0.065)$, while blood plasma concentrations showed the expected increase $(0 \cdot 172 \pm 0 \cdot 062$ to $3 \cdot 19 \pm 0 \cdot 68 \mathrm{ng} / \mathrm{ml})$.

\section{Discussion}

The results of the present study indicate that the concentration of native LH in the IEF in the testis surrounding the Leydig cells collected by two different techniques is very much lower than the concentration in blood plasma, both in unstimulated rats, and especially in those in which the concentration of LH in plasma had been increased by the injection of GnRH. While the concentration of $\mathrm{LH}$ in
IEF does increase slightly $30 \mathrm{~min}$ and later after the injection of $\mathrm{GnRH}$, there is no significant rise at $15 \mathrm{~min}$, and the rises at later times are much smaller than those in the plasma. Consequently, the highest levels found in IEF, even after maximal stimulation of LH secretion, are still less than those normally found in the blood plasma of unstimulated rats. While there is no change in the $\mathrm{LH}$ levels in IEF at $15 \mathrm{~min}$, there are small but significantly higher testosterone levels in testicular cells, IEF and TV blood plasma at this time, compared with saline-injected controls, when the values are expressed as ratios of the $15 \mathrm{~min}$ to the time 0 value for that individual. Therefore the Leydig cells appear to be responding by increasing testosterone production to such small increases in LH concentration that they cannot be proved statistically significant even when the values were obtained by the current analytical methods with greatly increased sensitivity. It seems most unlikely that LH is being degraded or altered immunologically in the IEF, as good recovery was found when amounts of $\mathrm{LH}$ comparable with those found in IEF were added to samples of IEF. It is not possible to say whether LH is being altered in vivo, but this seems most unlikely, and what we can measure in IEF samples would represent the normal circumstances. 

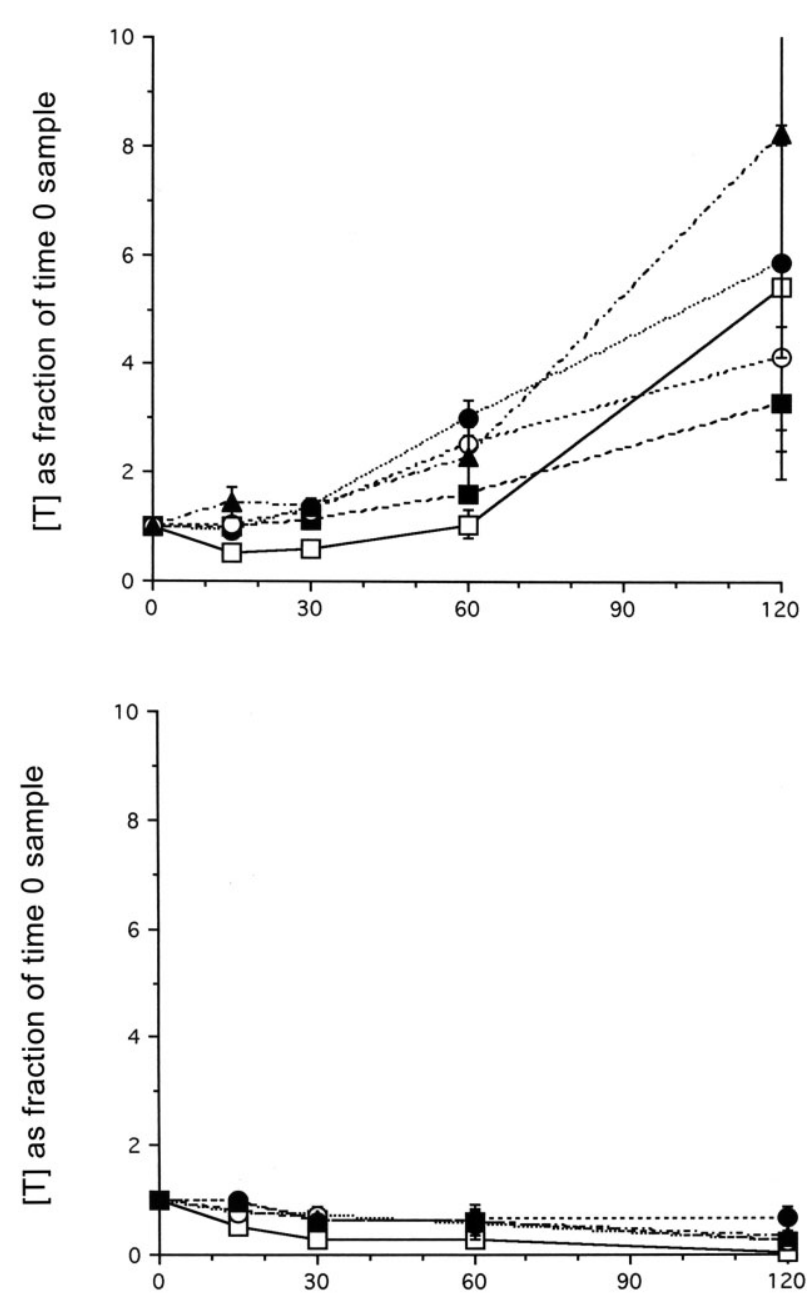

Time ( $\mathrm{min})$ after injection of saline

Figure 2 The means of the $t / 0$ ratios for individual animals of the $[T]$ at various times after injection to those before injection (time 0 ) in the same rats in PV plasma $(\square)$, TV plasma ( $\square)$, IEF $(\bullet)$, UF $(\bigcirc)$ and testicular cells $(\boldsymbol{\Delta})$ in the same rats as in Fig. 1 injected with (upper) either 1.5 or $0.5 \mu \mathrm{g} \mathrm{GnRH}$ or (lower) saline $(0.7 \mathrm{ml})$ at time 0 .

The present finding supports the physiological significance of the low LH concentrations that are measured in IEF before and after GnRH stimulation. It also corroborates earlier studies where rat testicular steroidogenic response to radioactively labelled hCG was measured (Huhtaniemi et al. 1982), and it was shown that a significant testosterone response occurred within $15 \mathrm{~min}$ after an intracardiac injection of hCG while, even after $60 \mathrm{~min}$, only between five and ten of the $20000 \mathrm{LH}$ receptors per Leydig cell were occupied by hormone ligand. Our value for the level of LH in IEF is about $0.25 \mathrm{ng} / \mathrm{ml}$, and if we assume that the standard is about $10 \%$ pure, this corresponds to $25 \mathrm{ng} / 1$ pure $\mathrm{LH}$. The molecular weight of LH is about 25000 , so this concentration is equivalent to about $1 \mathrm{pmol} / 1$. The equilibrium dissociation constant of $\mathrm{LH}$ binding is about $50 \mathrm{pmol} / 1$ (Huhtaniemi et al. 1982), and thus the present findings are in good agreement with the earlier data showing that very low LH levels and receptor occupancy can evoke a steroidogenic response from Leydig cells.

How then could the Leydig cells be sensing the stimulation? One possibility, already suggested by Sharpe (1981) for the similarly low values for iodinated hCG concentrations he found in IEF, was that a large proportion of the hormone in the testis was already bound to the Leydig cells, not free in the IEF. He based this conclusion on the assumption that iodinated albumin and iodinated hCG would enter the testis at the same rate, despite the large difference in size and degree of glycosylation of the two proteins. At $2 \mathrm{~h}$ after injection of the hormone, the shortest time he examined, the concentration in IEF was about three times that in the testis tissue, so that, even allowing for the fact that there was probably only about $100 \mathrm{mg}$ fluid and $1500 \mathrm{mg}$ cells, there would still be about $18 \%$ of the iodinated hCG free in the IEF. No data are available for native rat LH, and extrapolation of Sharpe's data back to $15 \mathrm{~min}$, the shortest time examined in the present study, would suggest that a higher proportion than $18 \%$ of the iodinated hCG would be free in the IEF at the earlier time. Huhtaniemi et al. (1982) reported that only about $10 \%$ of iodinated hCG was specifically bound to the testis receptor $1 \mathrm{~h}$ after injection, but again they did not study shorter times. Even if the present figues, because of binding to the cells, are a considerable underestimate of the true concentration of native rat LH in the IEF, the increase in concentration after GnRH would still be considerably less than that in the blood plasma. For example, $30 \mathrm{~min}$ after injection of $\mathrm{GnRH}$, the concentration of LH in IEF had risen from 0.078 to 0.230 , a rise of $0.152 \mathrm{ng} / \mathrm{ml}$; at the same time the concentration in blood plasma had risen from 0.66 to 6.14 , a rise of $5.48 \mathrm{ng} / \mathrm{ml}, 36$ times more, and this difference cannot be explained by the observed proportions of bound and free hormone.

Another possibility is that analyses of IEF as collected by either of the techniques used in the present study do not reflect the concentrations in the fluid in the immediate environment of the Leydig cells, but only in the whole fluid between the tubules, some of which may be quite distant from the Leydig cells. At present, this question cannot be addressed, as no techniques are available for collection of fluid only from the immediate neighbourhood of the Leydig cells, as opposed to the whole IEF and, in any case, the volume of such fluid would probably be insufficient for accurate analysis of $\mathrm{LH}$ concentrations. Another possibility is that rapid changes in LH concentrations in blood plasma are detected by the endothelial cells lining the blood vessels in the testis, and these cells transmit a signal to the Leydig cells by a hitherto unknown 
paracrine mechanism, similar to that suggested for adrenal cells (Roslowsky et al. 1999). The Leydig cells could still respond in the longer term to changes in the LH concentrations in their vicinity, but would not see the peaks of LH in the blood. Some support for this possibility can be found in the results of Ghinea et al. (1994) and Ghinea \& Milgrom (1995) who showed that endothelial cells in the testes of rats carried the same receptors for hCG as found on the Leydig cells, although these authors suggested that these receptors on the endothelial cells were involved in transcytosis of the hormone through the cells into the subendothelial space to reach the Leydig cells. To us it also seems possible that the receptor on the endothelial cells may also be involved in the response of the Leydig cells to rapid changes in LH concentrations in blood plasma through a local paracrine mechanism.

The levels of LH in the plasma of the rats in the present experiments, both in the unstimulated animals and after $\mathrm{GnRH}$ injection, are comparable with those reported in spontaneous peaks of LH secretion (Ellis and Desjardins 1982, Pierroz et al. 1999) although the rises seen here are probably of slightly greater duration than the spontaneous peaks. The concentrations in IEF are only slightly greater than those in the blood plasma of hypophysectomized rats reported by Haavisto et al. (1993). There were no significant differences between the concentrations of LH in PV and TV blood, which suggests that the uptake of LH by the testis is quite small.

What response would one predict from in vitro studies for Leydig cells with a change in the LH concentration from 0.1 to $0.25 \mathrm{ng} / \mathrm{ml}$, as found here in IEF at the later times after GnRH? Hakola et al. (1998) using incubated isolated mouse Leydig cells and rat pituitary LH RP-3 showed no increase in testosterone production with $\mathrm{LH}$ concentrations up to $2.5 \mathrm{ng} / \mathrm{ml}$ and about a $50 \%$ increase at $8 \mathrm{ng} / \mathrm{ml}$, with similar results with rat LH I-9 (Hakola et al. 1997). Other studies using incubated isolated Leydig cells (Ding \& Huhtaniemi (1989), with 1st IRP for pituitary LH 68/40 and Verhoeven \& Cailleau (1987) with sheep LH NIAMDD-oLH-23) or perifused Leydig cells (Wu et al. (1985) with NIH-oLH-23) are difficult to relate to the present findings because of cross-species differences in potency of the hormones used.

Another possibility to consider is that GnRH is itself having a direct effect on the Leydig cells. The highest dose of GnRH used here was $1.5 \mu \mathrm{g}$. If this is distributed through a volume of $20 \mathrm{ml}$, the approximate blood volume for a rat of the size used, it would result in a peak concentration of $75 \mu \mathrm{g} / \mathrm{l}$, or $6 \times 10^{-8} \mathrm{M}$, assuming a molecular weight of 1182 . As GnRH is a reasonably small molecule, it would probably distribute quite quickly through the whole extracellular fluid volume of about $100 \mathrm{ml}$, giving a concentration of about $1 \times 10^{-8} \mathrm{M}$. GnRH appears to increase testosterone production by incubated isolated Leydig cells only at concentrations of $3 \times 10^{-7} \mathrm{M}$ and higher (Sharpe \& Cooper 1982), so we believe that a direct effect of $\mathrm{GnRH}$ is unlikely in our experiments.

Comparable results were obtained for the concentrations of $\mathrm{LH}$, both before and after stimulation with $\mathrm{GnRH}$, in IEF collected using two different techniques. The mannitol irrigation technique used in the majority of the animals gives testosterone concentration gradients of about $5: 4$ between cells and IEF, 3:2 between IEF and TV plasma and 3:1 between IEF and UF. These ratios seem reasonable and agree quite well with those reported earlier (Setchell et al. 2000), although the absolute values were somewhat higher in the earlier study. In contrast, the drip technique gives absurdly high ratios in [T] between IEF and TV, unless testosterone production by the Leydig cells was suppressed (Maddocks \& Setchell 1989a), suggesting that testosterone was still being produced by the Leydig cells during the collection under normal circumstances. The more reasonable $[\mathrm{T}]$ ratios suggest that the mannitolirrigation technique does provide a better indicator of the composition of the interstitial fluid but, as the other less satisfactory technique has been widely used in other laboratories, it seemed wise to confirm our rather surprising results with an alternative method of collection.

The findings of very low concentration of LH in UF and the absence of any change in these levels after GnRH are consistent with earlier reports (Setchell et al. 1976), which showed that the concentrations of trichloroacetic acid- and immunoprecipitable iodinated rat LH in UF in rats was less than $10 \%$ of those in plasma up to $12 \mathrm{~h}$ after injection.

The final point to consider concerns the relationship between the $[\mathrm{T}]$ in cells, IEF, TV and UF. Although all these are significantly correlated, TV [T] did not rise as much as cell or IEF $[T]$, especially in rats in which testosterone secretion has been stimulated by LH released from the pituitary after GnRH injection. There was a much closer relationship between UF [T] and cell and IEF [T]. This suggests that there may be some restiction to movement of testosterone across the endothelial barrier, not across the tubular wall as previously suggested from comparison between TV and UF [T] and movement of isotopically labelled hormone (Setchell et al. 1978, Setchell 1980). The earlier results, lacking values for IEF [T], could as easily be explained by a restriction in movement of testosterone across the endothelium as across the tubular wall. However, the present results contrast with the finding of an increased TV to IEF [T] ratio $2 \mathrm{~h}$ after a large dose of hCG (Maddocks \& Setchell 1989b).

\section{Acknowledgements}

We are grateful to Ms T Laiho for running the LH assays, to Dr K Svechnikov for his assistance with the testosterone estimations and to STINT (Swedish Foundation for International Cooperation in Research and Higher 
Education) for a fellowship for B P S to work at the Karolinska Hospital in 2000.

\section{References}

Bousfield GR, Perry WM \& Ward DN 1994 Gonadotropin chemistry and biosynthesis. In The Physiology of Reproduction, edn 2, pp 1749-1792. Eds E Knobil \& JD Neill. New York: Raven Press.

Ding YQ \& Huhtaniemi I 1989 Human serum LH inhibitor(s): behaviour and contribution to in vitro bioassay of $\mathrm{LH}$ using dispersed mouse Leydig cells. Acta Endocrinologica 121 46-54.

Dufau ML 1995 The luteinizing hormone receptor. In The Leydig Cell, pp 333-350. Eds AH Payne, MP Hardy \& LD Russell. Vienna, IL: Cache River Press.

Ellis GB \& Desjardins C 1982 Male rats secrete luteinizing hormone and testosterone episodically. Endocrinology 110 1618-1627.

Galil KAA \& Setchell BP 1988 Effects of local heating of the testes on the concentration of testosterone in jugular and testicular venous blood of rats and on testosterone production in vitro. International Journal of Andrology 11 61-72.

Ghinea N \& Milgrom E 1995 Transport of protein hormones through the vascular endothelium. Journal of Endocrinology 145 1-9.

Ghinea N, Hai MTV, Groyer-Picard MT \& Milgrom E 1994 How protein hormones reach their target cells. Receptor-mediated transcytosis of hCG through endothelial cells. Journal of Cell Biology 125 87-97.

Haavisto AM, Pettersson K, Bergendahl M, Perheentupa A, Roser JF \& Huhtaniemi I 1993 A supersensitive immunofluormetric assay for rat luteinizing hormone. Endocrinology 132 1687-1691.

Hakola K, Boogaart PVD, Mulders J, de Leeuw R, Schonen W, Heyst PV, Swolfs A, Casteren PV, Huhtaniemi I \& Kloosterboer H 1997 Recombinant rat luteinizing hormone production: production by Chinese hamster ovary cells, purification and functional characterization. Molecular and Cellular Endocrinology 128 47-56.

Hakola K, Haavisto AM, Pierroz DD, Aebi A, Rannikko A, Kirjavainene T, Aubert ML \& Huhtaniemi I 1998 Recombinant forms of rat and human luteinizing hormone and follicle-stimulating hormone; comparison of functions in vitro and in vivo. Journal of Endocrinology 158 441-448.

Huhtaniemi IT, Clayton RN \& Catt KJ 1982 Gonadotropin binding and Leydig cell activation in the rat testis in vivo. Endocrinology 111 982-987.

Maddocks S \& Setchell BP 1988 The physiology of the endocrine testis. Oxford Reviews of Reproductive Biology 10 53-123.

Maddocks S \& Setchell BP 1989a Testosterone concentrations in testicular interstitial fluid collected with a push-pull cannula or by drip-collection from adults rats given testosterone or aminoglutethamide. Journal of Endocrinology 121 303-309.

Maddocks S \& Setchell BP $1989 b$ Effects of a single injection of human chorionic gonadotrophin on testosterone levels in testicular interstitial fluid and in testicular and peripheral venous blood in adult rats. Journal of Endocrinology 121 311-316.

Nnane IP, Njar VCO, Liu Y, Lu Q \& Brodie AMH 1999 Effects of novel 17-azolyl compounds on androgen synthesis in vitro and in vivo. Journal of Steroid Biochemistry and Molecular Biology 71 $145-152$.

Pierroz DP, Aebi AC, Huhtaniemi IT \& Aubert ML 1999 Many LH peaks are needed to physiologically stimulate testosterone secretion: modulation by fasting and NPY. American Journal of Physiology 276 E603-E610.

Roslowsky LJ, Hanke CJ \& Campbell WB 1999 Adrenal capillary endothelial cells stimulate aldosterone release through a protein that is distinct from endothelin. Endocrinology 140 4411-4418.

Setchell BP 1980 The functional significance of the blood-testis barrier. Journal of Andrology $13-10$.

Setchell BP 1994 Possible physiological bases for contraceptive techniques in the male. Human Reproduction 9 1081-1087.

Setchell BP, Hinton BT, Jacks F \& Davies RV 1976 Restricted penetration of iodinated follicle-stimulating and luteinizing hormone into the seminiferous tubules of the rat testis. Molecular and Cellular Endocrinology 6 59-69.

Setchell BP, Laurie MS, Main SJ \& Goats GC 1978 The mechanism of transport of testosterone through the walls of the seminiferous tubules of the rat testis. International Journal of Andrology (Suppl 2) 506-512.

Setchell BP, Plöen L \& Ritzén EM 2000 Reduction of long-term effects of local heating of the testis by treatment of rats with a GnRH agonist and an anti-androgen. Reproduction 122 255-263.

Sharpe RM 1981 The importance of testicular interstitial fluid in the transport of injected hCG to the Leydig cells. International Journal of Andrology 4 64-74.

Sharpe RM \& Cooper I 1982 Stimulatory effect of LHRH and its agonists on Leydig cell steroidogenesis in vitro. Molecular and Cellular Endocrinology 26 141-150.

Sharpe RM \& Cooper I 1983 Testicular interstitial fluid as a monitor for changes in the intratesticular environment in the rat. Journal of Reproduction and Fertility $69125-135$.

Turner TT \& Rhoades CP 1995 Testicular capillary permeability: the movement of luteinizing hormone from the vascular to the interstitial compartment. Journal of Andrology 16 417-423.

Verhoeven G \& Cailleau J 1987 A Leydig cell stimulatory factor produced by human testicular tubules. Molecular and Cellular Endocrinology 49 137-147.

Wu FCW, Zhang GY, Williams BC \& de Kretser DM 1985 Functional characterization of luteinizing hormone responsiveness and desensitization in perifused interstitiail cells. Molecular and Cellular Endocrinology 40 45-56.

Received 23 July 2002

Accepted 25 July 2002 